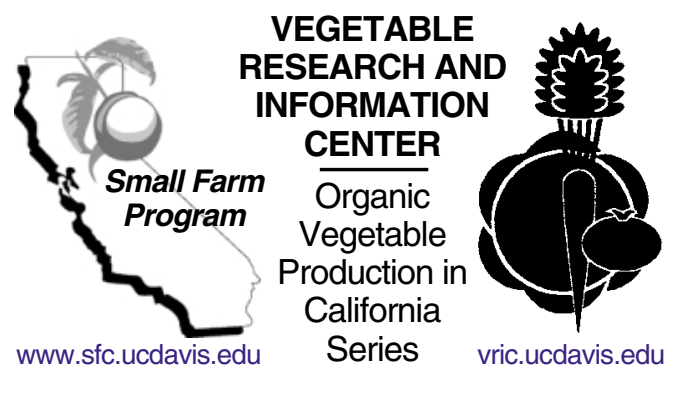

\section{INSECT PEST MANAGEMENT FOR ORGANIC CROPS}

\author{
CALVIN FOUCHE, UC Cooperative Extension Farm Advisor, \\ San Joaquin County; MARK GASKELL, UCCE Farm Advisor, \\ Santa Barbara and San Luis Obispo Counties; STEVEN T. KOIKE, \\ UCCE Farm Advisor, Monterey and Santa Cruz Counties; \\ JEFF MITCHELL, UCCE Vegetable Crops Specialist, \\ Kearney Agricultural Center, Parlier; and RICHARD SMITH, \\ UCCE Farm Advisor, Monterey and Santa Cruz Counties
}

Specific information on organic vegetable production practices in California is scarce, and growers need sound information
to guide their management decisions. The Organic Vegetable Production in California Series is made up of publications
written by Farm Advisors and Specialists from the University of California's Division of Agriculture and Natural
Resources. Each publication addresses a key aspect of organic production practices applicable to all vegetable crops.

Before planting a crop, an organic vegetable grower needs to understand the pests and beneficial organisms that usually occur in that crop and anticipate the pest problems that are likely to occur. Experienced growers act before problems reach devastating levels because they know that pests are more effectively controlled when their numbers are low. The major emphasis of insect pest management in organic vegetable production systems should be placed on the use of cultural and biological control methods.

By paying attention to crop rotations and crop residue incorporation, the grower can help prevent population buildup in many pest species. The practice of growing the same crop continuously, season after season, on the same piece of ground is an invitation to insect pests and diseases. In some locations, pest problems are so severe that it is not economically possible to grow certain crops organically using current technology. In areas of the San Joaquin Valley, for example, where lygus bugs migrate into fresh market bean fields, it is not possible to stop crop losses by using any of the available materials approved for organic vegetable growers. For the organic grower, the best solution to pest problems often will only come out of a thorough understanding of local conditions and a knowledge of what varieties or crops to grow and when to plant them in order to avoid the most severe problems. Good record keeping on pest problems-when they occur and what control strategies are effective-will help build a foundation for next year's pest control strategy.

\section{MONITORING FOR PESTS AND BENEFICIALS}

The correct identification of the pests and beneficials present in a crop is very important. Identification of the immature life stages such as eggs, nymphs, and larvae will greatly aid the grower's efforts to prevent economic damage to the crop. Many of the key pests in vegetable crops are described in pest management manuals and literature available from the University of California's Division of Agriculture and Natural Resources (see Resources). An experienced pest control advisor can alert a grower to potential problems before any crop losses occur.

If pheromone traps are available for key pest species, they can help determine the timing of population cycles and predict local increases in pest activity. In some situations, pheromones can be used to confuse males and prevent them from mating, thus reducing next-generation pest populations and the feeding damage they would cause. Be careful, though, to recognize when biological control factors are beginning to influence the pest population. Often, growers are unaware that beneficial insects and microorganisms are working to control pests, and they end up treating crops when they do not need to. By understanding the life cycle and biology of both pests and beneficials, you can make the most of the insect community that lives in the crop field.

To follow the activity of pests and beneficials in the crop, it is important that the grower make regular weekly checks in the field with a hand lens, inspecting the underside of foliage for the first signs of insect activity. Many pest species are very small and so often go unnoticed until they have caused considerable damage. More frequent checks may be necessary during periods of rapid increase for pests such as spider mites. Using a sweep net in cover crops, field edges, and adjacent crops, you can check for insect activity and help determine which beneficials or pests may be developing nearby with the potential to move into the crop.

The grower must identify tolerable levels or action thresholds for the particular pest species and crop. If it 
is a pest that feeds on the fruit or on a part of the vegetable that is sold, the tolerance for damage is generally lower. Pests feeding on portions of the plant that will not be sold, such as the leaves of a tomato plant, can often be tolerated at much higher levels.

\section{CULTURAL CONTROL}

You can coordinate the planting and harvesting dates to avoid certain pests that would otherwise build up in some crops. Sweet corn grown early in the summer, for instance, is subject to less danger of earworm damage than late-season corn. If aphid-transmitted virus diseases are a problem, successive plantings of the same crop will allow aphid populations to build up and damage late-season crops unless virus-resistant varieties are available. You may be able to reduce the spread of disease by planting later crops upwind of earlier-planted fields. In some areas, midsummer and lateseason plantings must be located in isolated fields. Other pests such as lygus, flea beetles, squash bugs, and many caterpillar species can build up in early crops and cause extensive damage in later plantings unless they are controlled before they can mature and reproduce.

Vegetable growers need to provide optimum growing conditions for their crops. Many plants are able to withstand insect feeding if they are actively growing and are able to compensate for some loss of foliage and root tissues. Soil type and nutrient content can effect crop vigor. Poor water management (especially too little water) can predispose plants to certain pests such as spider mites. Cover crops planted prior to the main cash crop can improve soil fertility and provide a valuable source of organic matter. Proper rotation of pestsusceptible main crops with non-susceptible varieties and cover crops can keep pest numbers low. The incorporation of a grass species into a rotation is often recommended, as grasses tend to be resistant to most of the insect and disease pests of common cash crops.

Field borders or strips within the field that are planted to species and varieties different from the main crop can provide habitat for beneficial arthropods and can slow the spread of pest species in the field. Flowering plants along borders and edges of fields can provide habitat and food for beneficial insects. Research in Yolo County has shown that substantial numbers of beneficial insects can move up to 250 feet from hedgerows into adjacent vegetable fields. Weed management in borders can be a challenge, and the grower will need to check the borders to make sure that pest species are not building up there and migrating out into cropping areas.

Crops such as alfalfa that attract pests away the main crop have been used in strawberries and cotton, and have potential for the organic vegetable grower. If the alternate crop (or trap crop) is maintained in a vigorous state, the pest may never even leave the trap crop. If the pest population builds up and begins to leave the trap crop, the trap crop can be mowed or sprayed to prevent damage to the main crop. The trap crop can also serve as an additional reservoir of beneficial predators and parasites in the event the adjacent crop field has to be treated.

Many of the true bugs (such as squash bugs, lygus, and stink bugs) overwinter outside of the field, so efforts to control them can be directed toward their winter and early spring sites before they move into the crops for the growing season. Also check box piles, lumber, and storage buildings for over-wintering pest species.

\section{MECHANICAL CONTROL}

Soil tillage can destroy insects and expose them to birds and other predators (see UC ANR Publication 7248, Soil Management and Soil Quality for Organic Crops). It can also speed the breakdown of plant residues that harbor insects and plant pathogens. By either allowing the organic matter in a field to decompose completely before you plant the next crop or allowing a fallow period between crops, you can enhance control of cutworms, root maggots, and bulb mites.

Certain soil and nutrient conditions can be associated with pest problems. High organic matter content, for instance, can lead to an increase in problems with symphylans, springtails, cutworms, wireworms, and root maggots. Sandy soils will tend to support higher nematode and wireworm populations. Organic growers farming on lighter soils have to be more careful with crops such as tomatoes, cucumbers, and root crops such as carrots. Longer fallow periods or more frequent grass rotations are necessary to prevent a buildup of soil pests. You can help prevent damage by growing sensitive crops when soil conditions are not favorable to pests. Fall- and winter-planted vegetables may escape damage that would be severe for the same crops if they were planted in spring or summer. Mechanical control in the form of vacuuming and destroying lygus bugs in strawberries has proven effective when the program includes frequent passes through the fields during critical pest periods.

Pest barriers can be incorporated into high-value vegetable plantings. Floating row covers and plastic tunnels effectively reduce access by many pest species. Reflective mulches have been effective for prevention of early aphid infestations in row crops such as tomatoes, squash, and eggplant. Sticky barriers can be useful as monitoring devices, but they have seldom been effective in themselves for control of pest species. 


\section{BIOLOGICAL CONTROL}

The organic farmer should strive to conserve the many naturally occurring beneficial organisms that are present in the crop. If it were not for the naturally occurring biological control factors, most crops would be inundated with dozens of pests. If you find it necessary to treat for a particular pest in order to prevent economic losses, choose a selective spray material and use only enough of it to keep damage levels within economically acceptable limits. Short-residual pesticides will allow beneficial insects and predator mites to return to the field and help control remaining or newly introduced pest species.

An organic farming system offers many opportunities for enhancing biological control factors. Since most organic farms apply little or no harsh pesticides, it is possible to build up large numbers of beneficial parasites and predators that help control pests in many crops. The introduction of biocontrol organisms to a field may be most cost effective when a grower is making the transition from conventional to organic production systems. Make sure that the introduced pest is well adapted to the particular climate or site and that it is the correct species for the pest that you wish to control. When purchasing biological control agents, buy from a reputable supplier. Multiple releases of the biological control agents may be required in order to bring pest populations to very low levels. Suppliers will often assist with suggestions for managing introduced biological control agents.

When pests such as aphids build to large populations, they will often be controlled by ladybird beetles, lacewings, syrphid flies, or wasp parasites. For many growers this control may come too late to prevent extensive damage to the crop. If alternate plants are allowed to support aphids in high numbers early in the season, the predators and parasites that develop on those aphids may later move into the crop. If the aphids are vectors of viral pathogens, it will only take a few of them to cause extensive losses. In this case, predators and parasites will not effectively prevent the spread of disease into or through the field.

Many caterpillar pests infest vegetable crops. Trichogramma wasps can be highly effective in preventing caterpillar damage. The wasps parasitize the eggs of pest species, killing the pests before any feeding injury can occur. When purchasing Trichogramma wasps, buy the species that is appropriate for the intended pest and make frequent releases of enough wasps to control the pest. In many situations, this will require multiple weekly releases of millions of wasps. When releasing live organisms, it often is wise practice to set some of them aside and check to make sure they are still viable at the time of release. Heat, cold, time, and diseases all can affect the viability of biological control agents.

\section{CHEMICAL CONTROL}

A number of organically acceptable insecticides are available, and each may be useful to you in specific circumstances. For up-to-date information, see the UC IPM website listed in the Resources section at the end of this publication. If you do plan to use organically acceptable pesticides, several factors should be considered.

Low mammalian toxicity. The materials selected should not present a health risk to the applicator or the people who must work in the crop after application. Although most organically approved pesticides are relatively safe, their use does involve some risks. The highest level of risk is often present when the materials are in concentrate form and are being added to the spray tank. Materials such as sulfur can cause skin and eye irritation during application and for some time afterward. Some individuals may develop an allergic reaction to pesticides or the solvents used in the formulation process.

Minimal effect on beneficial organisms. While many selective pesticides are directly toxic only to pest species, their use can cause disruption to nontarget beneficial species by eliminating their insect hosts and thus starving the beneficial species or prompting them to migrate out of the field. This indirect reduction of beneficials may allow the remaining pest population to increase to higher levels if their reproductive potential exceeds that of the remaining beneficials.

Adequate coverage essential. Thorough coverage of the plant is important with almost all organically acceptable pesticides. For many pests, the young insect or mite can be found on the underside of the leaf surface and must have direct contact with the spray material for control to be achieved. In many cases, high volumes of water are necessary to get the pesticide to the target. As much as 100 or 200 gallons of water or more per acre may be required to achieve thorough coverage of the leaves of vegetable plants.

Often, the best sprayer nozzle configuration will direct the spray to the underside and interior of the plant, with as many as six nozzles for each row. Higher pressure at the nozzle tips will break the water up into smaller droplets, and often help the material reach the interior of the plant. The nozzle size should be matched to the application pressure to produce the desired droplet size for optimum coverage.

Many growers are finding that air blast and electrostatic sprayers can provide excellent coverage without requiring the high volumes of water needed by conven- 
tional spray equipment. The initial cost for air-blast equipment is higher than for conventional sprayers, but the savings in time taken to refill the tank can allow a grower to treat more crops in a given period of time. Soil compaction can be reduced if less water is being carried across the field. Proper timing of the spray to intercept the pest in a susceptible stage is important no matter what equipment you use to deliver the product.

Many organically approved pesticides degrade rapidly in the environment. Control of a continuing pest problem may require repeated applications. Because insects can become resistant to pesticides that are used frequently, those pesticides will become less effective over time. This is not so common with shortresidual pesticides as with materials that have a long residual activity. Pests are not likely to develop resistance to materials such as oils and soaps that use physical actions such as suffocation or physically dislodging the pest from the crop as their mechanism of control.

Here are some examples of pests that can be controlled by organically approved materials:

- Aphid populations can be reduced with oils, soaps and pyrethrum/rotenone combinations. If ants are protecting the aphids from predators and parasites, the best control is often achieved by controlling the ants and allowing biological control to resume in the crop. Ant colonies can be physically destroyed or treated with boric acid baits.

- Whitefly populations can be suppressed by multiple applications of soaps and oils. Since the pupal stage is resistant to control, it is important that you make at least two applications close enough together to prevent more pupal stages from occurring. Thorough coverage of the underside of the leaves is important, as this is where most of the whitefly nymphs will be feeding.

- Leafminer control may require several applications within a two-week period. Many of the pupae are in the soil and will not be controlled with short-residual materials. Sprays containing azadirachtin, pyrethrins, and rotenone will kill some of the adults and help to limit the population. Sprays for leafminers will slow the build-up of native wasp parasites.

- Leafhopper numbers can be reduced with applications of pyrethrins and rotenone if the nymphs come into contact with the materials. Adults and eggs that are inserted in the plant tissues will not be controlled very well with chemicals.
- If flea beetle numbers are high when young plants are in the cotyledon stage, you can reduce damage from adults by applying soaps and pyrethrin/rotenone combinations.

- Stinkbugs can be difficult to control, and only the first two instars are susceptible to soap sprays. If allowed to build up in the field to high levels, they cannot be controlled with organically approved chemical treatments.

- Russet mites can be controlled with sulfur sprays or dusts. Light mineral, vegetable-based, or neem seed oils can be effective against pest mites. Some damage to crop foliage or fruit can occur when you use oils. It is advisable to treat a test area first before applying the material to the whole field if you have not usedthe product before on that crop. Hot weather and higher oil concentrations can increase the toxic reaction in the plants.

- Worm pest control can be difficult in many crops. Bacillus thuringiensis (Bt) formulations are available that enable the organic grower to limit damage from worms. Smaller worms are controlled more easily by this method, and since the Bt must be ingested by the worm thorough coverage of al leaf surfaces is necessary. For best results, these materials should be applied early, as control will lag several days behind the application. Worms must be controlled before they enter into the fruits or go deep into foliage where they will not ingest the spray residues.

For each of the above pests and treatments, thorough coverage if necessary for effective control. The coverage obtained and the timing of the spray application can be more important that the choice of material. In many situations, a combination of materials will be more effective than a single product alone.

\section{OTHER PUBLICATIONS IN THIS SERIES}

Organic Certification, Farm Production Planning, and Marketing, UC ANR Publication 7247

Soil Management and Soil Quality for Organic Crops, UC ANR Publication 7248

Soil Fertility Management for Organic Crops, UC ANR Publication 7249

Weed Management for Organic Crops, UC ANR Publication 7250

Plant Disease Management for Organic Crops, UC ANR Publication 7252 


\section{RESOURCES}

\section{Beneficial Insects and Biological Control Agents}

Cal/EPA, Department of Pesticide Regulation has the most complete and up-to-date resource list, available by phone or downloaded from their website. The title is Suppliers of Beneficial Organisms in North America, and the author is Charles Hunter Phone: (916) 324-4100

Website: http:/ /www.cdpr.ca.gov /

\section{Equipment and Supplies}

BioQuip Products, for field lenses and insect collecting, counting, and preserving supplies. Extensive list of books on insects Phone: (310) 324-0620

E-mail: bioquip@aol.com

Gemplers, for insect monitoring tools, field lenses and safety equipment

Phone: 1-800-382-8473

Website: http:/ / www.gemplers.com

Great Lakes IPM, for monitoring and field lenses Phone: (517) 268-5693

Peaceful Valley Farm Supply, for insect monitoring tools, beneficial insects, biological control agents, floating row covers, and organically approved pesticides

Phone: 1-888-784-1722

Website: http:/ /www.groworganic.com

\section{Information}

California Department of Pesticide Regulation

County Agricultural Commissioners

Local organic growers' association chapters

Local nurserys

Local UC Cooperative Extension Farm Advisors

Private pest control advisors (PCAs) and crop consultants

UC IPM website: http:/ /www.ipm.ucdavis.edu/

UC Sustainable Agricultural Research and Education

Program website: http:/ / www.sarep.ucdavis.edu/

\section{Publications}

Long, R. 1998. Beneficial insects move from flowering plants to nearby crops. California Agriculture Magazine, September-October.

University of California Integrated Pest Management (IPM) manuals, including Pests of the Garden and Small Farm,

UC ANR Publication 3332

Natural Enemies Handbook,

UC ANR Publication 3386

Integrated Pest Management for Tomatoes,

UC ANR Publication 3274

Integrated Pest management for Cole Crops and Lettuce,

UC ANR Publication 3307

Integrated Pest Management for Potatoes in the Western

United States, UC ANR Publication 3316

An electronic version of this publication is available on the University of California ANR Communication Services webite at http:/ / anrcatalog.ucdavis.edu.

Publication 7251

(C) 2000 by the Regents of the University of California,

Division of Agriculture and Natural Resources. All rights reserved.

To simplify information, trade names of products have been used. No endorsement of named products is intended, nor is criticism implied of similar products that are not mentioned.

The University of California prohibits discrimination against or harassment of any person employed by or seeking employment with the University on the basis of race, color, national origin, religion, sex, physical or mental disability, medical condition (cancer-related or genetic characteristics), ancestry, marital status, age, sexual orientation, citizenship, or status as a covered veteran (special disabled veteran, Vietnam-era veteran or any other veteran who served on active duty during a war or in a campaign or expedition for which a campaign badge has been authorized).

University Policy is intended to be consistent with the provisions of applicable State and Federal laws.

Inquiries regarding the University's nondiscrimination policies may be directed to the Affirmative Action/Staff Personnel Services Director, University of California, Agriculture and Natural Resources, 1111 Franklin, 6th Floor, Oakland, CA 94607-5200 (510) 987-0096. 